\title{
Caroli syndrome in a dog
}

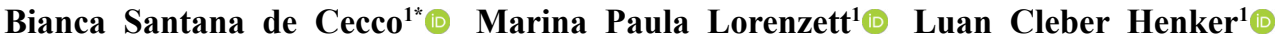 \\ Juliana Bisol ${ }^{2}$ (i) Aline Girotto Soares $^{3}$ (i) Anelise Bonilla Trindade-Gerardi ${ }^{2}$ (b) \\ Marcelo Meller Alievi² ${ }^{(1)}$ Luciana Sonne $^{1}$ (i)
}

\author{
${ }^{1}$ Setor de Patologia Veterinária, Universidade Federal do Rio Grande do Sul (UFRGS), 90540-000, Porto Alegre, RS, Brasil. \\ E-mail: biasantanacecco@gmail.com. ${ }^{*}$ Corresponding author. \\ ${ }^{2}$ Hospital de Clínicas Veterinárias, Universidade Federal do Rio Grande do Sul (UFRGS), Porto Alegre, RS, Brasil. \\ ${ }^{3}$ Instituto de Pesquisas Veterinárias Desidério Finamor (IPVDF), Eldorado do Sul, RS, Brasil.
}

ABSTRACT: Caroli syndrome is characterized by a combination of intrahepatic biliary ductal ectasia and congenital ductal fibrosis due to the failure of involution of ductal plates and large intrahepatic ducts. This study aims to report Caroli syndrome in a dog, with emphasis on clinical characteristics, complementary examinations, and diagnostic approach. A 1-year-old mixed-breed intact male dog was presented with a 7-day history of acute vomiting and anorexia. Clinical evaluation revealed severe jaundice, abdominal pain, dehydration, lethargy, and abdominal distension. Ultrasonography revealed hepatic cysts filled with fluid. Exploratory laparotomy was performed to clarify the imaging findings; however, the dog died shortly after surgery. Postmortem examination revealed that the liver was reduced in size and had multiple interconnected and distended saccular dilations. The bile ducts were markedly dilated and replaced a large part of the liver parenchyma. Multiple small cysts were also observed in the kidneys. Microscopically, the hepatic lesions were characterized by extensive bridging fibrosis associated with proliferating and ectatic bile ducts contiguous with the biliary tree. Marked fibrosis and small cysts were observed in the kidneys. Therefore, a final diagnosis of Caroli syndrome was made. While uncommon, this syndrome should be considered as a differential diagnosis for young dogs with biliary cysts and hepatic fibrosis.

Key words: liver cysts, Caroli syndrome, malformation, genetic condition.

Síndrome de Caroli em um cão

RESUMO: A sindrome de Caroli é caracterizada pela combinação de ectasia biliar intra-hepática e fibrose ductal congênita, que se devem a falha na involução das placas ductais dos grandes ductos intra-hepáticos. Esse trabalho tem a intenção de reportar um caso de síndrome de Caroli em um canino, com ênfase em suas características clínicas, exames complementares, e abordagem diagnóstica. Um canídeo de um ano de idade, sem raça definida, apresentou um histórico clínico de sete dias de vômito agudo e anorexia. A avaliação clínica revelou severa icterícia, dor abdominal, desidratação, letargia e distensão abdominal. A ultrassonografia foi sugestiva de cistos hepáticos preenchidos por fluido. Uma laparotomia exploratória foi realizada para esclarecer os achados de imagem, porém, o cão morreu logo após a cirurgia. O cão foi submetido a exame de necropsia, onde se observou figado diminuído em tamanho e com múltiplas dilatações saculares distendidas e interconectadas entre si. Os ductos biliares estavam acentuadamente dilatados e substituiam grande parte do parênquima hepático. Nos rins, múltiplos pequenos cistos eram observados. Microscopicamente as lesões hepáticas eram caracterizadas por extensa fibrose em ponte, associada a ductos biliares ectáticos e proliferados, que eram contíguos a árvore biliar. Nos rins, marcada fibrose e pequenas formações císticas foram observadas. Baseado na associação dos achados clínicos e patológicos, o diagnóstico de síndrome de Caroli foi feito. Mesmo que incomum, essa síndrome deve ser considerada como um diagnóstico diferencial para cães jovens com ductos biliares císticos e fibrose hepática.

Palavras-chave: cistos hepáticos, Sindrome de Caroli, má-formação, condição genética.

Hepatocytes and bile ducts have the same hepatoblast precursors. The differentiation between these two liver components is orchestrated by regulatory factors and genes responsible for the formation of the ductal plate (ARNON et al., 2010; NGUYEN TRUONG \& YEH, 2010). Caroli disease is the direct result of the failure of involution of ductal plates, which leads to the formation of large intrahepatic ducts. The condition is characterized by multiple large intrahepatic cysts that are contiguous with the biliary tree (NGUYEN TRUONG \& YEH, 2010). Caroli syndrome is characterized by a combination of intrahepatic biliary ductal ectasia and congenital ductal fibrosis (GÖRLINGER et al., 2003; NGUYEN TRUONG \& YEH, 2010; PILLAI et al., 2016). In dogs, several cases of Caroli's disease and syndrome have been associated with significant renal cyst formation (GÖRLINGER et al., 2003; HELGERT 
\& SULA, 2019). Although Caroli malformations in humans are associated with genetic abnormalities, these specific mutations have not been identified in dogs (HELGERT \& SULA, 2019). To the best of our knowledge, there have been only two reports of Caroli syndrome in dogs and a report of Caroli's-type ductal plate malformation in a cat (PILLAI et al., 2016; ROBERTS et al., 2018; HELGERT \& SULA, 2019). Herein, we describe the clinical and gross histological features of Caroli syndrome in a dog.

A 1-year-old mixed-breed male dog was submitted to clinical evaluation after presenting with a 7-day history of acute vomiting, lethargy, and anorexia. The dog presented with an exfoliative lesion on the scrotum. Without veterinary advice, the owner gave the $\operatorname{dog} 375 \mathrm{mg}$ of paracetamol once a day for 2 consecutive days and $5 \mathrm{mg}$ of metoclopramide hydrochloride twice daily for 2 days. The vomiting became more frequent since the onset of the treatment, and the dog started presenting with obtundation and a stumbling gait. The owner also reported that the dog presented sporadic vomiting episodes since it was a puppy; however, the condition worsened in the previous week. Clinical examination revealed regular body condition, abdominal distension, severe jaundice, abdominal pain, dehydration (7\%), rectal temperature of $37.5^{\circ} \mathrm{C}$, and lethargy. Abdominal palpation revealed a soft mass of unknown origin, occupying a significant part of the abdominal cavity.

Blood samples were collected from the jugular vein, and complete blood count (CBC) and partial serum biochemical tests were performed. CBC was performed using an automatic blood analyzer Procyte Dx (IDEXX $\left.{ }^{\circledR}\right)$ and revealed normocytic normochromic anemia (hematocrit of $20 \%$; reference value: $37-55 \%$ ) and severe leukocytosis (leukocytes of $43,200 \mu \mathrm{L}$; reference value: $6,000-17,000$ $\mu \mathrm{L}$ ), with neutrophilia (neutrophils of $40,176 \mu \mathrm{L}$; reference value: $3,000-11,500 \mu \mathrm{L})$. Neutrophil morphology showed signs of toxicity. Biochemical evaluation revealed alanine aminotransferase (ALT) of 2,559 UI/L (reference value: 10-120 UI/L), alkaline phosphatase (ALP) of $1739 \mathrm{U} / \mathrm{L}$ (reference value: 16$140 \mathrm{U} / \mathrm{L}$ ), creatinine of $3.4 \mathrm{mg} / \mathrm{dL}$ (reference value: $0.7-1.5 \mathrm{mg} / \mathrm{dL}$ ), and urea of $100 \mathrm{mg} / \mathrm{dL}$ (reference value: $10-30 \mathrm{mg} / \mathrm{dL}$ ). The coagulation parameter, activated partial thromboplastin time (aPTT), was also increased (41.3 s; reference value: 9-11 $\mathrm{s}$ ) (THRALL, 2012).

Abdominal ultrasonography was performed using Mylab 40VET (Esaote Healthcare ${ }^{\circledR}$ ) (Figure 1A). The results revealed a liver parenchyma with increased echogenicity and interspersed with multiple large cystic areas filled with fluid. Kidneys had an irregular capsular surface and moderate to severe reduction in the corticomedullary definition. To clarify the imaging findings and collect liver samples for biopsy analysis, the dog underwent exploratory laparotomy. The anesthetic protocol included methadone $(0.3 \mathrm{mg} / \mathrm{kg}$, subcutaneous $)$ as a pre-anesthetic medication and induction with ketamine $(5 \mathrm{mg} / \mathrm{kg}$, intravenous) and midazolam (0.3 $\mathrm{mg} / \mathrm{kg}$, intravenous). Anesthetic maintenance was performed using isoflurane with bupivacaine $(2 \mathrm{mg} /$ $\mathrm{kg}$ ), an intra-abdominal splash effect. During the surgical procedure, the dog presented hypotension, and continuous norepinephrine infusion $(0.1 \mathrm{mg} / \mathrm{kg} / \mathrm{h})$ was administered. Post-surgical analgesia included methadone $(0.3 \mathrm{mg} / \mathrm{kg}$, subcutaneous) and dipyrone $(25 \mathrm{mg} / \mathrm{kg}$, subcutaneous). After a period of $20 \mathrm{~h}$ following surgery, the dog died and was submitted for a postmortem examination.

Grossly, the abdominal cavity contained $200 \mathrm{~mL}$ of light green and viscous liquid associated with fibrin filaments. The liver was small (Figure 1B) and partially replaced by interconnected saccular dilations (2.0-20 cm in diameter) (Figure 1C). These dilations (cysts) grossly resembled the gallbladder, which could not be differentiated from the cysts. The remaining hepatic parenchyma had a coppery color and multiple portosystemic shunts. Kidneys were irregular and pale, with numerous small cysts in the cortical region $(0.2-0.6 \mathrm{~cm}$ in diameter) (Figure 1D). Additional gross lesions included mild wall thickening of the small and large intestines. The pancreas was firm. No alterations were observed in the other organs. Samples of several organs were collected, fixed in 10\% neutral buffered formalin (for $36 \mathrm{~h}$ ), processed routinely for histopathology (3 $\mu \mathrm{m}$ sections), and stained with hematoxylin and eosin. Hepatic and renal sections were subjected to Masson's trichrome (MT) staining.

Histopathologically, the hepatic lesions were characterized by large cystic formations lined by cylindrical epithelial cells, interspersed by marked proliferation of fibrous connective tissue (fibrosis) (evidenced by MT staining) (Figure 2A, and B). Frequently, these areas were associated with bile duct proliferation (mainly small ducts) filled with amorphous eosinophilic material. Both cysts and bile ducts were lined by a similar epithelium, and these structures appeared to be contiguous with the biliary tree. Occasionally, multifocal, mild inflammatory infiltrate composed of lymphocytes, plasma cells, neutrophils, and macrophages containing granular intracytoplasmic hemosiderin were observed. 


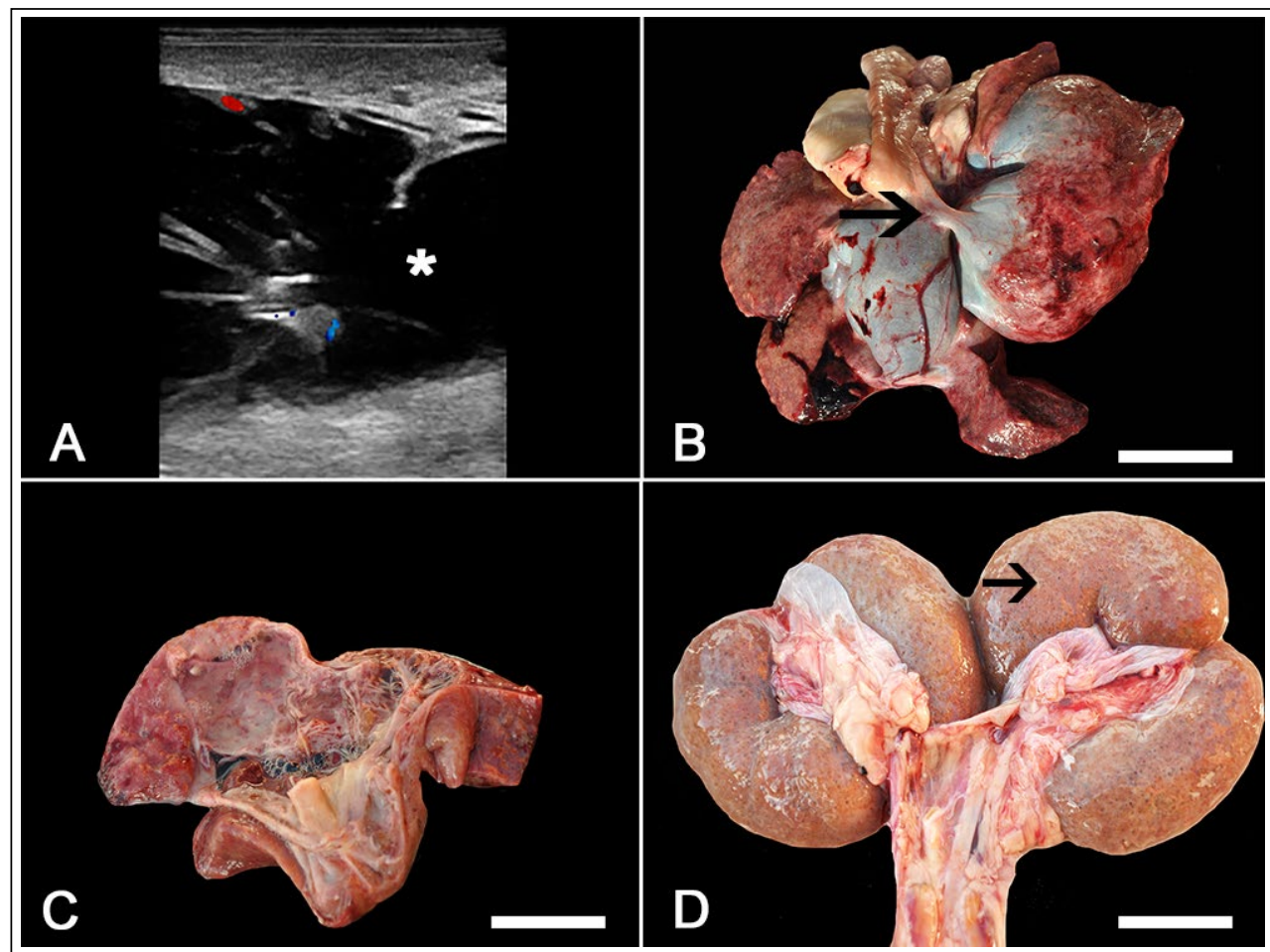

Figure 1 - Gross changes in a dog with Caroli syndrome. (A) Ultrasonographic images of the liver demonstrating the cystic formation (asterisk). (B) Multifocal to coalescing large cysts replacing the liver parenchyma. Cysts appear to be contiguous to the biliary tree (arrow). Bar: $5 \mathrm{~cm}$. (C) At cut surface, one of the distended sacculation. Bile ducts are markedly ectatic. Bar: $2 \mathrm{~cm}$. (D) Cut surface of the kidney. Fusiform radially arranged cysts (arrow) and fibrosis are present throughout the cortex with marked fibrosis of the medulla. Bar: $2 \mathrm{~cm}$.

Some of the remaining hepatocytes adjacent to the proliferating biliary ducts were necrotic and dissociated. The kidneys had diffuse marked interstitial fibrosis (also evidenced by MT staining), glomerular atrophy, tubular ectasia, and multiple small cysts lined by a simple cuboidal epithelium. The renal tubules were filled with necrotic debris and mild neutrophilic infiltrate (Figure 2C). Intestines exhibited diffuse, moderate inflammatory infiltrates composed of lymphocytes and plasma cells in the lamina propria. The pancreas had multifocal areas of moderate inflammatory infiltrate composed of macrophages and lymphocytes. The adipose tissue surrounding the pancreas had severe, multifocal to coalescent areas of necrosis associated with neutrophilic infiltrate (Figure 2D).

The diagnosis of Caroli syndrome was made based on clinical and pathological findings, which were large saccular dilations (cysts) of the bile ducts, extensive bridging fibrosis in the liver, and cyst formation and interstitial fibrosis in the kidneys. The pathological features observed in our case are highly compatible with those of Caroli syndrome previously described in dogs (PILLAI et al., 2016; HELGERT \& SULA, 2019). Although Caroli malformations are frequently associated with kidney and pancreatic cysts in humans, only hepatic and renal cystic presentations are significant in dogs (GÖRLINGER et al., 2003; ARNON et al., 2010; HELGERT \& SULA, 2019). Biliary dysplastic syndromes have been commonly reported in certain dog breeds, such as Cairn Terriers, West Highland White Terriers, and Golden Retrievers, and the affected dogs are usually young and ranging in age from 6 months to 3 years (CENTER, 2009; HELGERT \& SULA, 2019).

Clinical features cannot distinguish dogs with Caroli syndrome from those with other hepatopathies, such as cholangitis, since liver 


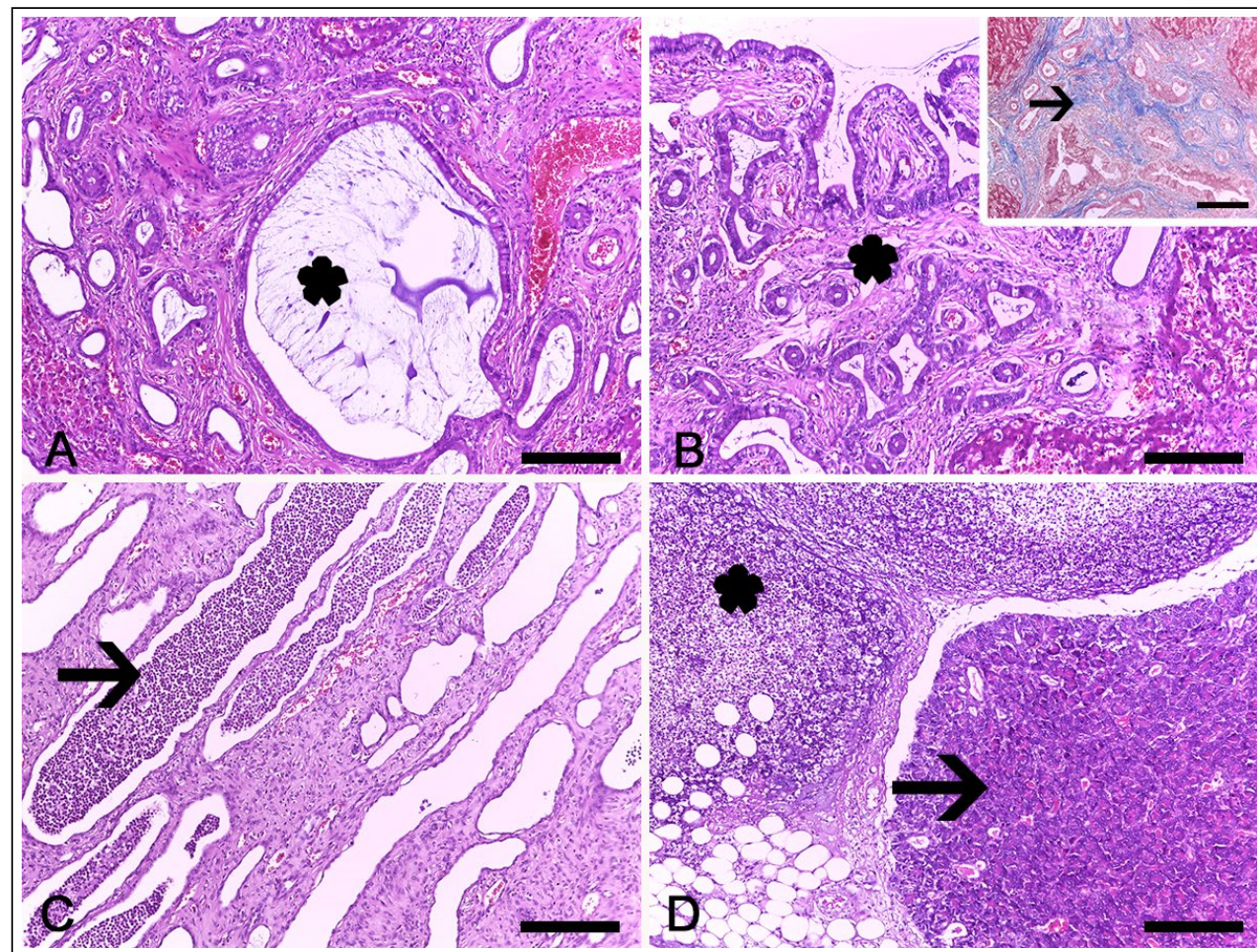

Figure 2 - Pathological findings in a dog with Caroli syndrome (A) Photomicrograph of the liver. Marked bile duct proliferation associated with cystic formation (asterisk). The cysts and the bile ducts have similar epithelium. The cysts are contiguous to the biliary tree (H\&E, bar: $100 \mu \mathrm{m})$. (B) Photomicrograph of the liver. Fibrotic portal area characterized by mature connective tissue (asterisk) with dilated irregularly formed bile ducts lined with cylindrical epithelium. (H\&E, bar: $100 \mu \mathrm{m})$. Inset: Photomicrograph of the liver. Fibrotic portal area

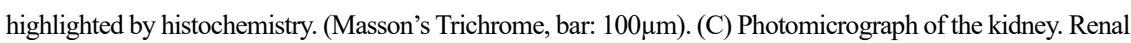
cortex with large elongated cyst surrounded by dense mature fibrous tissue; normal tubules and glomeruli can

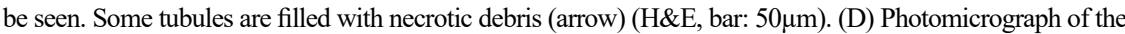
pancreas and peripancreatic tissue. The peripancreatic tissue presents severe, multifocal to coalescent areas of necrosis associated with neutrophilic infiltrate (asterisk). The pancreas has normal architecture (arrow). (H\&E, bar: $50 \mu \mathrm{m})$.

enzymes (ALT and ALP) may be increased and the abnormalities in coagulation parameters could indicate hepatic failure with coagulopathy. In humans, a possible sequela of ductal plate malformation is cholestasis due to ascending cholangitis, cholelithiasis, and secondary hepatic fibrosis (PILLAI et al., 2016). These findings are consistent with the hepatic lesions observed in our case, where the dog probably demonstrated severe jaundice due to cholestasis. Although the pancreas did not present any cysts, the other microscopic lesions of the organ exhibited findings similar to those described in humans with Caroli malformations (FAHRNER et al., 2018). Dogs can also have a poor prognosis related to progressive renal insufficiency, as observed in this case. Commonly, renal lesions can lead to an increase in creatinine levels observed clinically.

Hepatorenal fibrocystic diseases, including Caroli disease, polycystic liver disease, and congenital hepatic fibrosis, are the main differential diagnoses in this case. The presence of multiple intrahepatic cysts contiguous with the biliary tree without hepatic fibrosis characterizes Caroli disease (GÖRLINGER et al., 2003; ARNON et al., 2010). In congenital hepatic fibrosis, there is abundant bridging hepatic fibrosis without cystic formation (PILLAI 
et al., 2016). Congenital hepatic cystic disease is characterized by multiple proliferation and dilatation of segments of the intrahepatic bile ducts (not contiguous with the intrahepatic biliary tree), varying degrees of fibrosis, and inflammatory infiltrates associated with polycystic kidney and pancreatic disease (GÖRLINGER et al., 2003; STALKER \& HAYES, 2007). These three hepatorenal fibrocystic diseases have been described in dogs and, in this case, were excluded based on pathological findings.

Mutations in the PKHD1 gene have been reported in horses with congenital hepatic fibrosis (MOLÍN et al., 2018). Most pathogenic PKHD1 variants lead to polycystic kidney and liver defects; however, in some cases, only liver symptoms are observed, as described in horses with a monogenic autosomal recessive inheritance that presents congenital hepatic fibrosis (DRÖGEMÜLLER et al., 2014). In West Highland White and Cairn Terrier dogs, polycystic renal and liver diseases appear to be inherited in an autosomal recessive fashion and are similar to the perinatal form of autosomal recessive polycystic kidney disease in children (McALOOSE et al., 1998). Mutations in the PKDl gene are associated with polycystic kidney disease in Persian cats and Bull Terrier dogs (mutation c.9772G $>A$ in exon29), resembling the adult form of polycystic kidney disease in humans (GHARAHKHANI et al., 2011; CULLEN \& STALKER, 2016). A report of congenital hepatic fibrosis and polycystic kidney in a Persian cat demonstrated the absence of a classic genetic mutation, hypothesizing distinct etiopathogenesis among fibropolycystic diseases in domestic cats (GUERRA et al., 2015). In other reported cases of Caroli syndrome in dogs (PILLAI et al., 2016; HELGERT \& SULA, 2019), no specific mutation for PKD1 was identified.

With an appropriate therapeutic approach, dogs affected by Caroli syndrome can live for several years, as described in the case of a 6-yearold dog diagnosed as a puppy (HELGERT \& SULA, 2019). In human medicine, the treatment is focused on the drainage of bile via endoscopy and can include segmental liver resection, with or without transplantation (FAHRNER et al., 2018); however, in veterinary medicine, the disease can be managed through diet and the use of ursodiol, an antifibrotic substance that has a prokinetic effect on the biliary tree (HERGERT \& SULA, 2019). Caroli disease, a less severe disease, can be managed with a proteinrestricted diet (GÖRLINGER et al., 2003).

In conclusion, this report provides clinical information and pathological descriptions of Caroli syndrome in dogs. Although rare in dogs, Caroli syndrome should be considered as a differential diagnosis in young dogs with liver abnormalities.

\section{ACKNOWLEDGMENTS}

We thank Conselho Nacional de Desenvolvimento Científico e Tecnológico (CNPq) and Coordenação de Aperfeiçoamento de Pessoal de Nível Superior (CAPES) for financial support. This study was financed in part by the Coordenação de Aperfeiçoamento de Pessoal de Nível Superior (CAPES), Brasil - Finance code 001. The author also acknowledges the services of image of the Veterinary Hospital of the Universidade Federal do Rio Grande do Sul.

\section{DECLARATION OF CONFLICT OF} INTEREST

The authors declared no potential conflicts of interest with respect to the research, authorship, and/or publication of this article.

\section{AUTHORS' CONTRIBUTIONS}

All authors contributed equally to the conception and writing of the manuscript. All authors critically revised the manuscript and approved the final version.

\section{REFERENCES}

ARNON, R. et al. Caroli disease, Caroli syndrome and hepatic fibrosis. In: MURRAY, K.F.; LARSON, A.M. Fibrocystic diseases of the liver. Berlin: Springer Science, 2010. p. 331-358.

BOURQUE, A.C. et al. Congenital hepatic fibrosis in calves. The Canadian Veterinary Journal, v.42, p.145-146, 2001. Available from: <https://pubmed.ncbi.nlm.nih.gov/11272462/>. Accessed: Feb. 12, 2021. Doi: 10.4141/cjas62-025.

CENTER, S.A. Diseases of gall bladder and biliary tree. Veterinary Clinics: Small Animals Practice, v.39, p.543-598, 2009. Available from: <https://pubmed.ncbi.nlm.nih.gov/19524793/>. Accessed: Feb. 12, 2021. Doi: 10.1016/j.cvsm.2009.01.004.

CULLEN, J.M.; STALKER, M.J. Liver and Biliary system. In: MAXIE, M.G. Pathology of Domestic Animals, Jubb, Kennedy \& Palmer's. 6.ed. St. Louis, Missouri: Elsevier, 2016. p.265.

DRÖGEMÜLLER, M. et al. Congenital Hepatic Fibrosis in the Franches-Montagnes Horse Is Associated with the Polycystic Kidney and Hepatic Disease 1 (PKHD1) Gene. Plos One, v.9, n.10., p.e110125, 2014. Available from: <https://journals.plos.org/ plosone/article?id=10.1371/journal.pone.0110125>. Accessed: Jul. 21, 2021. Doi: 10.1371/journal.pone.0110125.

FAHRNER, R. et al. Liver resection and transplantation in Caroli disease and syndrome. Journal of Visceral Surgery, v.156, n.2, p.91-95, 2018. Available from: <https://pubmed.ncbi.nlm. nih.gov/29929811/>. Accessed: Feb. 12, 2021. Doi: 10.1016/j. jviscsurg.2018.06.001. 
GHARAHKHANI, P. et al. A Non-synonymous mutation in the Canine Pkd1 Gene Is Associated with Autosomal Dominant Polycystic Kidney Disease in Bull Terriers. Plos One, v.6, n.7, p. e22455, 2011. Available from: <https://pubmed.ncbi.nlm.nih. gov/21818326/>. Accessed: Feb. 12, 2021. Doi: 10.1371/journal. pone. 0022455 .

GÖRLINGER, S. et al. Congenital dilatation of the Bile Ducts (Caroli's Disease) in Young Dogs. Journal of Veterinary Internal Medicine, v.17, p.28-32, 2003. Available from: <https://pubmed. ncbi.nlm.nih.gov/12564724/>. Accessed: Feb. 12, 2021. Doi: 10.1892/0891-6640(2003)017<0028:cdotbd $>2.3$.co; 2 .

GUERRA, J.M. et al. Congenital hepatic fibrosis and polycystic kidney disease not linked to $\mathrm{C}>\mathrm{A}$ mutation in exon 29 of PKD1 in a Persian cat. Journal of Feline Medicine and Surgery Open Reports, v. 1, n.2, 2015. Available from: $<$ https://pubmed.ncbi.nlm.nih.gov/28491400/>. Accessed: May. 18, 2021. Doi: 10.1177/2055116915619191.

HELGERT, N.D.; SULA, M,M. Caroli syndrome in a six-Year Old Rottweiler Dog. Journal of Comparative Pathology, v.167, p.15, 2019. Available from: <https://www.sciencedirect.com/science/ article/abs/pii/S0021997518302676>. Accessed: Feb. 12, 2021. Doi: 10.1016/j.jcpa.2018.11.004.

McAlOOSE, D. et al. Polycystic kidney and liver Disease in Two Related West Highland White Terriers Litters. Veterinary Pathology, v.35, p.77-81, 1998. Available from: <https://pubmed. ncbi.nlm.nih.gov/9545140/>. Accessed: Feb. 12, 2021. Doi: $10.1177 / 030098589803500110$.

MOLÍN, J. et al. Congenital hepatic fibrosis in a Purebred Spanish Horse Foal: Pathology and Genetic Studies on PKHD1 Gene
Mutations. Veterinary Pathology, v.55, n.3, p.457-461, 2018. Available from: <https://pubmed.ncbi.nlm.nih.gov/29402207/>. Accessed: Feb. 12, 2021. Doi: 10.1177/0300985817754122.

NGUYEN TRUONG, C.D.; YEH, M.M. Pathology of fibrocystic diseases of the liver. In: MURRAY, K.F.; LARSON, A.M. Fibrocystic diseases of the liver. Berlin: Springer Science; 2010. p.133-55.

PATNAIK,A.K. etal. Caninehepatic neoplasms:Aclinicopathologic study. Veterinary Pathology, v.17, p.553-564, 1980. Available from: <https://pubmed.ncbi.nlm.nih.gov/7404966/>. Accessed: Feb. 12, 2021. Doi: 10.1177/030098588001700504.

PILLAI, S. et al. Ductal plate malformation in the Liver of Boxer Dogs: Clinical and Histological Features. Veterinary Pathology, v.53, n.3, p.602-613, 2016. Available from: <https://pubmed. ncbi.nlm.nih.gov/26797094/>. Accessed: Feb. 12, 2021. Doi: $10.1177 / 0300985815610567$.

ROBERTS, M.L. et al. Caroli's-type ductal plate malformation and a portosystemic shunt in a 4-month-old kitten. Journal of Feline Medicine and Surgery Open Reports, v.4, n.2, p. 1-5, 2018. Available from: <https://www.ncbi.nlm.nih.gov/pmc/articles/ PMC6247498/pdf/10.1177_2055116918812329.pdf>. Accessed: May. 18, 2021. Doi: 10.1177_2055116918812329.

STALKER, M.J.; HAYES, M.A. Liver and biliary System. In: MAXIE, M.G. Pathology of Domestic Animals, Jubb, Kennedy \& Palmer's. 6.ed. St. Louis, Missouri: Elsevier, 2007. p. 297-388.

THRALL, M.A., et al. Veterinary hematology and Clinical Chemistry. Ames, IA: Wiley- Blackwell, 2012, 2205p. 
Ciência Rural, Santa Maria, v.52:12, 2022

$10.1590 / 01038478 \mathrm{crerr} 20210238$

e10238

Erratum

(c) (i)

\section{Erratum}

In the article "Caroli syndrome in a dog" published in Ciência Rural, volume 52, number 9, DOI http://dx.doi.org/10.1590/0103-8478cr20210238.

In the author's where we read:

Anelise Bonilha Trindade-Gerardi

Read:

Anelise Bonilla Trindade-Gerardi 